DOI https://doi.org/10.18551/rjoas.2017-05.21

\title{
INTEGRATING THE CONCEPTS OF CITY BRANDING AND TOURISM EVENT ON BEHAVIOURAL INTENTION IN DOMESTIC URBAN TOURISM
}

\author{
Kusumawati Andriani \\ Business Administration Department, University of Brawijaya, Indonesia \\ E-mail: andriani kusuma@ub.ac.id
}

\begin{abstract}
Despite the significance of city branding in both academia and industry, literature on its conceptual development is limited. The current study aims to explain and test a theoretical model of city branding, which integrates the concepts of the tourism event on decision to visit and intention to revisit. Type of this research was explanatory, and data was collected by distributing questionnaires to 116 domestic tourists in Banyuwangi, Indonesia. Path analysis was used to analyse the data. The study results show that city branding and tourism event directly and indirectly affect intention to revisit through decision to visit. It is proposed that the decision to visit is a mediator between city brand and tourism event influence on intention to revisit. The results confirmed that intention to revisit is influenced by decision to visit which is a critical mediator between city brand and tourism event. It suggested that government and entrepreneurs in tourism sector should consistently maintain city branding of Banyuwangi and to promote more tourism attractions in order to increase tourist visits to Banyuwangi. In addition, creating synergy among travel agents and initiating more innovative tourism event are also become policy recommendation that should be taken into account by the goverment.
\end{abstract}

\section{KEY WORDS}

City branding, tourism event, decision to visit, revisit intention, Banyuwangi, Indonesia.

The growing research has concentrated on tourism sector since it has contributed to the economic growth. Tourism previously is used to be a tertiary need, now it becomes a primary need. The tourism is a business that increasing rapidly, therefore, it needs an appropriate strategy that enables to manage the tourism potential of each region. From this perspectives, the destination needs to be unique and differential to be selected as a final decision. Thus, the concept of city branding is critical for a destination to be identified and differentiated from alternatives in the minds of the target market.

Brand is an identity that cannot be separated from a product either in the form of services or goods. Kotler and Keller (2009) reveal that brand is a name, term, sign, symbol or design and its combination that is aimed to identify goods or services of one of the sellers or a group of sellers and differentiate it from the competitors. Anholt in Moilanen and Rainisto (2009) defines the city branding as an image management of a destination through strategic inovation and coordination of economic, commercial, social, cultural, and government regulation. The role of city branding is to create positioning and difference to introduce the potential of the region to their tourists.

One of the region potential is attraction in terms of events or festivals. According to Mill (2000) the attraction is an area that is developed earlier to attract the attention of the visitors. Attraction is something that can attract the tourists or a destination that serves different characteristics of each region. Usually, event functioned as one of the strengths of local governments and societies to attract the tourists to visit a particular destination.

As one of small city in Indonesia with has a lot of interesting culture, Banyuwangi conducted a regular festivals to promote their unique culture as part of tourism agenda of the region. The tourism development of Banyuwangi use the continuous concept such as annual event namely Banyuwangi Festival. In 2016, Banyuwangi Festival has a theme "EXPLORE BANYUWANGI you must want to come back". Along with the city branding "The Sunrise of Java", Banyuwangi use the events to attract domestic and international tourist. 
According to Liu (2015), city branding can give an impression so that it increases the care and strengthens positioning on the brand that functions to invite the tourists. Yoeti (2002) reveals that event has functions as tourism education by showing the culture or custom of local people in daily life. City branding and event can create the perception to the visitors so that it can stimulate the decision to visit. In addition, create the pleasure so it appropriate pushes to explore more the attraction in Banyuwangi that impact on shaping attitudes of intention to revisit.

\section{LITERATURE REVIEW}

City branding is a management of destination through strategic innovation and coordination of economic, social, commercial, cultural, and government's regulation (Anholt in Moilanen and Rainisto, 2009). Kavaratzis and Ashworth (2005) mention that city branding is a concept that is generally practiced by few cities in context of competitions that attract the tourists and investment of environment intensively to promote the regional development. City branding is a strategy that gives brand to the city that functions as a tool to introduce or market the potential of region to all stakeholders from local to internationals. One of purposes of city branding is to attract the investors' and tourists' attention to develop and market the potential of tourism that is owned.

City Branding has a function as a tool to communicate places (city, regency, or province) to the stakeholders (Yananda and Salamah, 2014). Anholt creates city branding hexagon to measure the effectivity of city branding. According to Anholt (2007) the measurement of effectivity of city branding consists of six aspects namely Presence, Potential, Place, Pulse, People, Prerequisite (see Figure 1).

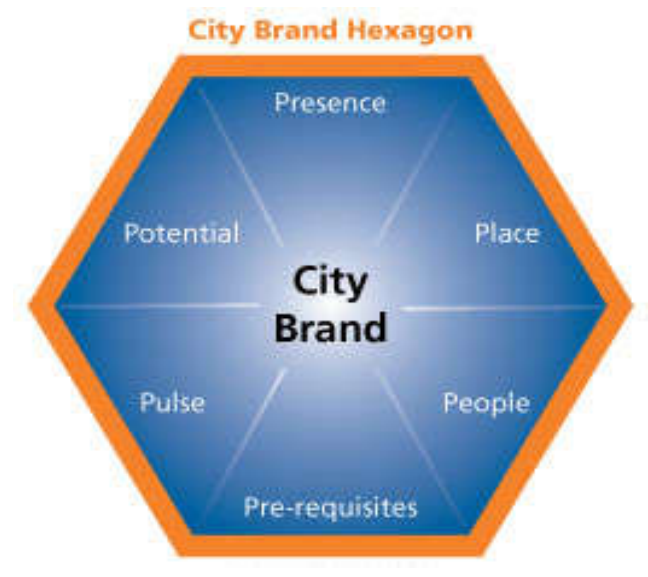

Source: Anholt (2007).

Figure 1 - City Brand Hexagon

According to Getz (2008), event is something that happens as an output or part of any activities. Noor (2009) asserts that event is an activity that is held to commemorate important things, either individually or in a group. Event is an attraction that can be in the form of tradition, sports, culture, ritual of religion, and certain celebration. Moreover, Yoeti (2002) explains that the success of a destination and industry of tourism really depend on attraction, accessibility, and amenities.

The decision making of consumer is a process of interaction between affective attitude, cognitive attitude, behavioral attitude with enviroment factor and people that do changes in all aspects of life (Peter and Olson in Nitisusastro, 2012). The decision to visit in this research is concept that is equal to the decision of buying. Nitisusastro (2012) defines a decision to visit as a stage of last process from a series of process stages that happen in the consumers' behaviors. The decision to visit is a process that is faced by the consumers before visiting that involves finding the information (knowledge) and need of product or 
destination, so that they want it that then making a decision to visit that place after passing some stages.

The experience that is obtained by the consumer from a product with a certain brand will make positive impression on that product and the consumer will buy again (Hellier et al., 2003). The intention of re-buying is a form of positive behavior after buying; in this condition the concept of intention of visit is same with the intention of re-buying. The intention to revisit is a form of tourists' care about destination based on previous experience (McKercher and Wong, 2004). The intention to revisit is an intention that refers to the willingness of tourists to visit the same destination (Um et al., 2006). Butcher (2005) argues that the intention of consumers to re-buy is one of success measurement of a company, especially Service Company.

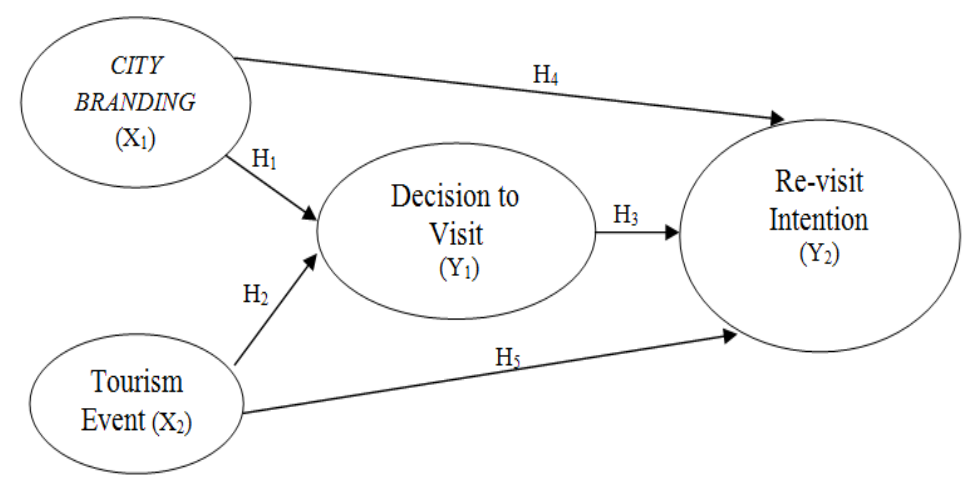

Figure 2 - Research Model

The following is hypotheses of this research:

$\mathrm{H}_{1}$ : City branding significantly influences on decision to visit;

$\mathrm{H}_{2}$ : Event significantly influences on decision to visit;

$\mathrm{H}_{3}$ : Decision to visit significantly influences to the on intention on revisit;

$\mathrm{H}_{4}$ : City branding significantly influences on intention to revisit;

$\mathrm{H}_{5}$ : Event significantly influences on intention to revisit.

\section{METHODS OF RESEARCH}

Type of research that is used is explanatory research with quantitative approach. A small city namely Banyuwangi was chosen since this region has an anual festival that quite famous in Indonesia. Four variables under researched were city branding, event of tourism, decision to visit and intention to revisit. This research employs purposive sampling technique to obtain 116 sampel from domestic tourist in some places when Banyuwangi Festival conducted. Questionnaires were distributed to obtain the research data. Path analysis and descriptive analysis were conducted to analyse the data of research.

\section{RESULTS OF RESEARCH}

Based on the result of the research it shows that 116 respondents that consist of $49.1 \%$ men and $50.9 \%$ women. The large amount of respondents originate from East Java province which is $73.3 \%$ or 85 people while the rest spreads from Central Java, West Java, Jakarta, Yogyakarta and Bali. Respondents in this research ranged from the youngest age of 18 years old up to the oldest age of 42 years old. However, the largest amount of respondent were aged of 28 years old which is 12 people (10.3\%). Largely, respodent in this research were tourists that have visited Banyuwangi with the last educational background is bachelor degree.

The whole tourists that become respondent in this research mentions that they know "The Sunrise of Java" as a brand of Banyuwangi regency. Largely, 71 people or $61.2 \%$ 
respodents state that they have visited Banyuwangi twice. Vacation is the most reason of respondents to visit which consist of 103 people or $88.8 \%$.

Six indicators in city branding with the mean score of each: (4.38) potential (4.39) place (4.46), pulse (4.33), people (4.31), pre-requisite (4.26). Variable of event has three indicators with mean score of each: attraction (3.77), accessibility (3.69) and amenities (3.69). Structure of decision to visit is an indicator of variable of decison of visit with mean score (3.79). Trasactional, referential, preference and eksplorative are indicators of intention to revisit variable. Those four indicators have mean score of each: transactional (3.69), referential (3.62), preference (3.70) and eksplorative (3.72).

The influence of city branding on decision to visit has beta coefficient of $-0.178, t_{\text {count }}-2.220$ with probability 0,028 . Value of probability on the result of analysis is smaller than $0.05(p<\alpha)$, it can be concluded that $\mathrm{H}_{0}$ is rejected. Thus, first hypothesis in this research states that city branding has a significant influence on decision to visit $\left(\mathrm{H}_{1}\right)$ is accepted.

Table 1 - Result of Test of Path Analysis

\begin{tabular}{|c|c|c|c|c|c|}
\hline Exogenous Variable & Endogenous Variable & $\beta$ & $\mathrm{T}_{\text {test }}$ & Probability & Note \\
\hline City Branding & Decision to visit & -0.178 & -2.220 & 0.028 & Sig \\
\hline Event & Decision to visit & 0.507 & 6.317 & 0.000 & Sig \\
\hline Decision to visit & intention to revisit & 0.404 & 4.356 & 0.000 & Sig \\
\hline City Branding & Intention to revisit & 0.181 & 2.241 & 0.027 & Sig \\
\hline Event & Intention to revisit & 0.200 & 2.176 & 0.032 & Sig \\
\hline
\end{tabular}

The influence of event on decision to visit has beta coefficient of $0.507, \mathrm{t}_{\text {test }} 6.317$ with probability 0.000 . Probability value in the result of analysis is smaller than $0.05(p<\alpha)$, it can be concluded that $\mathrm{H}_{0}$ is rejected. Therefore the second hypothesis in this research states that, event has a significant influence on decision to visit $\left(\mathrm{H}_{2}\right)$ is accepted.

The influence of decision to visit on the intention to revisit has beta coefficient of 0.404 , $t_{\text {test }} 4.356 \mathrm{I}$ with probability 0.000 . Probability value in the result of analysis is smaller than $0.05(p<\alpha)$, it can be concluded that $\mathrm{H}_{0}$ is rejected. Thus, the third hypothesis in the research that states decision to visit affects significantly on intention to revisit $\left(\mathrm{H}_{3}\right)$ is accepted.

The influence of city branding on the intention to revisit has beta coefficient of 0.181 , $t_{\text {test }} 2.241$ with probability 0.027 . Probability value in the result of research is smaller than 0.05 $(p<\alpha)$, it can be concluded that $\mathrm{H}_{0}$ is rejected. Therefore, the fourth hypothesis in the research states that, city branding affects significantly on intention to revisit $\left(\mathrm{H}_{4}\right)$ is accepted.

The influence of variable of event on the intention to revisit has beta coefficient of $0.200, t_{\text {test }} 2.176$ with probability 0.032 . Value of probability in the result of analysis is smaller than $0.05(p<\alpha)$, it can be concluded that $\mathrm{H}_{0}$ is rejected. Therefore, the hypothesis in the research states that event affects significantly on intention to revisit $\left(\mathrm{H}_{5}\right)$ is accepted.

\section{DISCUSSION OF RESULTS}

The result of direct path analysis shows that variable of city branding has a significant influence on the variable of decision to visit, with the level of contribution value $(-0.178)$ or ($17.8 \%)$. Based on that result it can be concluded that the negative sign on the influence of city branding to the decision to visit shows that the variable of city branding is not the only consideration to visit Banyuwangi residence. Dealing with brand of Banyuwangi "The Sunrise of Java", domestic tourists pay attention more on the tagline as a tool to know a city in forming the decision to visit.

The finding of this research also underlined Anholt' (2007) point of view that the function of city branding as a tool in promoting the potential of city to attract the attention of societies widerly. This promotion is aimed to increase the number of visit of tourists, develop tourism event, increase economic power and introduce culture. City branding which is intentioning can function as an emotion attraction or tourists' attention to visit that place (Winfield-Pfefferkorn, 2005). 
The result of direct path analysis shows that event variable has a significant influence on the decision to visit with contribution $0.507(50.7 \%)$. Based on that result it can be concluded that the decision to visit is influenced by positive event. In contrast, if the judgment of the tourists is negative, so it tends to cause the cancellation of decision making to the event. This result supports the research findings conducted by Fitriani and Andari (2013) that there is a relation and influence between variable of event on the Museum of Asia Africa Conference and decision to visit in the city of Bandung.

In each region that has potential of an attraction, it can be used for special event as an additional attraction that conducive the high tourism visit (Getz and Page 2015). In this current condition Banyuwangi also use event as a tool to promote the potential of tourism. Festival is something that cannot be separated from tourism activity because it could attract the tourists (Cudny, 2013). Event has a significant impact or influence on the decision to visit and help to increase the popularity of city (Getz, 2008).

The result of direct path analysis shows that variable of decision to visit has significant influence on the intention to revisit with the contribution value $0.404(40.4 \%)$. Based on that result it can be concluded that the intention to revisit is influenced by positive visit decision. Banyuwangi as the tourism destination can give positive experience to the tourists, so it has a big opportunity to attract the intention of tourists to visit again. This result supports the opinion from Kotler and Armstrong (2008) that states on the evaluation stage, the consumer forms preference on the brands that exist in the collection of choices, and at that time it also forms the intention to buy the product that they like.

The result of decision to visit shows that city branding variable has significant influence on the intention to revisit with the contribution $0.181(18.1 \%)$. Based on that result, it can be concluded that city branding is one of variables that gives positive influence on the tourists to form an intention to revisit. This proves that "The Sunrise of Java" can give good impression for the tourists to decide the intention or intention to revisit to Banyuwangi regency.

This research supports the research result conducted by Hellier et al. (2003) that states, strong brand has direct influence on forming the intention of re-buy. This research also supports the research conducted by Filieri and Lin (2016) that states, there is positive relation between brand and intention to revisit. The research result is supported by the opinion of Chiu and Won (2016) that states, to form the intention of re-buy it needs commitment of strong brand. According to Silva (2013) destination brand can influence the tourists easily to visit the same city again.

The result of direct path analysis shows that event variable has a significant influence on the revisit intention with contribution $0.200(20 \%)$. Based on that result it can be concluded that the intention to revisit is influenced by positive event. Based on that result it can be concluded that event is one of variables that gives significant influence on the tourists to form the intention to revisit. The impact of tourists' experience when visiting, it gives positive impression so that it forms the want or intention to revisit. This research result supports the research conducted by Yu et al. (2012) event in Shanghai in 2010 that can influence significantly to the variable of intention to revisit.

This research also support previous research result from Kuusik et al. (2014) that states a certain event has significant influence on the tourists' behavior to visit that lead to the next visit. This research highlighed the idea of Grappi and Montanari (2011) that event or festival can attract and increase the attention of tourists. The explorative intention is an intention of tourist to explore each event or attraction provided by the government or businessmen of tourism of Banyuwangi regency. Thus, the tourists do not feel bored because they get different attraction visit in each visit to Banyuwangi.

\section{CONCLUSION}

City branding variable has a significant influence on the decision to visit. This indicates that tourist use variable city branding as the consideration to visit Banyuwangi regency. Event variable has significant influence on the decision to visit. This indicates that the tourist judge positively B-Fest event so that it makes event as the consideration to make a decision 
to visit in Banyuwangi regency. Variable of decision to visit has significant influence on the intention to revisit. This shows that the tourist feel happy so that there is a tendency to form the intention to revisit to Banyuwangi regency.

City branding variable has significant influence on the intention to revisit. It proves that the tourist judges positively "The Sunrise of Java" as a brand of Banyuwangi regency, so the tourist recommends to other people, look for the information related to it and visit again in the future. Event variable has significant influence on the intention to revisit. It means that the tourist judges positively and feels happy for the visit to Banyuwangi regency. So the impact, the tourist has a tendency to visit again and make the B-Fest event as the preference of their holiday.

It is recommended that the government of Banyuwangi should develop more strategiy to positioning their city brand by promoting "The Sunrise of Java" and more Banyuwangi Festival. In addition, synergizing with the businessmen of tourism could be done to increase the intensity of tourism visit. Another strategy through the development of promotion program that describes the condition of Banyuwangi would be helpful to increase the awareness of the region. This concept could be focused on the fields of culture, natural resources and the strengthness of societies' economy.

It is suggested that the government of Banyuwangi can increase the number of tourist through cooperation with tour or travel agent, through the development of event and new policy to facilitate the business tourism activities. The new policy is related to the easyness of business permission, the forming of business group, so that the entrepreneurs in tourism sector can help to increase the number of tourism visit. This research is still limited to the variables of city branding, event, the decision to visit and intention to revisit. It is suggested that in the future research could use other variables and different research methods to obtain more comprehensive results.

\section{REFERENCES}

1. Anholt, S. (2007). Competitive identity: The new brand management for nation, cities and regions. Palgrave Macmillan, USA.

2. Butcher, K. (2005). Differential impact of social influence in the hospitality encounter. International Journal of Contemporary Hospitality Management, 17: 125-135.

3. Chiu, W. and Won, D. (2016). Consumenr-brand relantionships in sports products and repuchase intention. International Journal of Sport Marketing, 17: 243-259.

4. Cudny, W. (2013). Festival tourism - the concept, key functions and dysfunctions in the context of tourism geography studies. Geographical Journal, 65(2): 105-118.

5. Fitriani, M. and Andari, R. (2013). Meningkatkan keputusan berkunjung melalui event di Museum Konferensi Asia Afrika. Tourim and Hospitality Essentials Journa, 3(2).

6. Filieri, R. and Lin, Z. (2016). The role of aesthetic, cultural, utilitarian and branding factor in young Chinese consumers' repurchase intention of smartphone brands. Computers in Human Behavior, 67: 139-150.

7. Getz, D. (2008). Event tourism: definision, evolution, and research. Tourism Management, 29: 403-428.

8. Getz, D. and Page, S.J. (2015). Progress and prospects for event tourism research. Tourism Management, xxx: 1-39.

9. Grappi, S and Montanari, F. (2011). The role of indentification and hedonism in affecting tourist re-patronizing behaviours. Tourism management, 32: 1128-1140.

10. Hellier, P.K., Geursen, G.M., Carr, R.A. and Rickard, J.A. (2003). Customer repurchase intention: A general equation model. Europeaan Journal of Marketing, 37:1762-1800.

11. Kavaratzis, M. and Ashworth, G.J. (2005). City branding: an effective assertion of identity or a transitory marketing trick. Tijdschrift voor Economische en Sociale Geografie, 96(5): 506-514.

12. Kotler, P. and Keller, K.L. (2009). Manajemen pemasaran. 13th Edition. Erlangga, Jakarta. 
13. Kotler, P. and Armstrong, G. (2008). Prinsip-prinsip pemasaran. 12th Edition. Bob Sabran (Ed.). Erlangga, Jakarta.

14. Kuusik, A., Nilbe, K., Mehine, T. and Ahas, R. (2014). Country as a free sample: the ability of tourism events to generate repeat visits. Case study with mobile positioning data in Estonia. Procedia-Social and Behavioral Sciences, 148: 262-270.

15. Liu, Yi-De. June (2015). Major event and city branding. Journal of Place Management and Development, 8: 147-162.

16. Mckercher, B. and Wong, D. (2004). Understanding tourism behaviour: examining the combined effects of prior visitation history and destination status. Journal of Travel Research, 43(2): 171-9.

17. Mill, R.C. (2000). The internasional business. Tri Budi Sastrio (Ed.). PT Raja Gravindo Persada, Jakarta.

18. Moilanen, T. and Rainisto. (2009). How to Brand Nations, Cities and Destinations, a Planning Book for Place Branding. Palgrave Macmillan, USA.

19. Nitisusastro, H.M. (2012). Perilaku Konsumen dalam Perspektif Kewirausahaan. Alfabeta, Bandung.

20. Noor, A. (2009). Manajemen event. 1st Edition. Alfabeta, Bandung.

21. Silva, L.D. (2013). Determinants of destination branding for revisiting: with special reference to tourism in Sri Langka. University of Paredeniya, Paredeniya.

22. Um, S., Chon, K. and Ro, Y.H. (2006). Antecedents of revisit intention. Annals of Tourism Research, 33(4): 1141-1158.

23. Winfield-Pfefferkorn, J. (2005). The Branding of Cities Exploring City Branding and the Importance of Brand Image. Master of Arts in Advertising Design at the Graduate School of Syracuse University, August.

24. Yananda, M.R. and Salamah, U. (2014). Branding Place. Meaning Information, Jakarta.

25. Yoeti, O. (2002). Perencanaan Strategi Pemasaran Daerah Tinjauan Wisata. PT Angkasa, Bandung.

26. Yu, L., Wang, C. and Seo, J. (2012). Mega event and destination brand: 2010 shanghai expo. Internasional Journal of Event and Festival Management, 3: 46-65. 